\title{
The supergene mineral association with brandholzite from Pernek, Malé Karpaty Mountains, Slovak Republic
}

\author{
Jiří SEJKORA ${ }^{1, *}$, Daniel OZDÍN ${ }^{2}$, Rudolf ĎUĎA ${ }^{3}$ \\ ${ }^{1}$ Department of Mineralogy and Petrology, National Museum, Václavské nám. 68, 11579 Prague 1, Czech Republic; \\ jiri_sejkora@nm.cz \\ ${ }^{2}$ Department of Mineralogy and Petrology, Faculty of Natural Sciences, Comenius University, Mlynská dolina, 84215 Bratislava, \\ Slovak Republic \\ ${ }^{3}$ Bystrická 87, 04011 Košice-Perěs, Slovak Republic \\ * Corresponding author
}

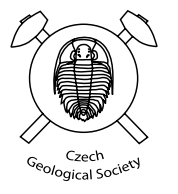

Brandholzite, a hydrated hydroxide of $\mathrm{Mg}^{2+}$ and $\mathrm{Sb}^{5+}$, was found at the Krížnica deposit near Pernek (Malé Karpaty Mountains, Slovak Republic); it is the third occurrence of this mineral phase worldwide. Crystals and crusts of brandholzite occur as surface coatings on altered shales mineralized with stibnite and pyrite. Associated minerals include roméite-like phases, sulphur, aragonite, gypsum, sénarmontite and Sb-rich Fe-hydroxides. Brandholzite forms euhedral tabular crystals of hexagonal habit, typically 0.5 to $0.8 \mathrm{~mm}$ across, exceptionally up to $2 \mathrm{~mm}$ long. The crystals occur as isolated, or randomly grouped individuals, creating inconspicuous crusts up to several $\mathrm{cm}^{2}$. Brandholzite crystals are colourless, transparent or showing white clouding. No fluorescence was observed under either short- or long-wave $\mathrm{UV}$ radiation. The average electron microprobe analysis gave $6.11 \mathrm{MgO}, 0.52 \mathrm{CaO}, 0.16 \mathrm{FeO}, 55.89 \mathrm{Sb}_{2} \mathrm{O}_{5}$ and (37.32) $\mathrm{H}_{2} \mathrm{O}$ if recast to $100 \mathrm{wt}$ \% $\%$. The calculated formula is $\left(\mathrm{Mg}_{0.88} \mathrm{Ca}_{0.05} \mathrm{Fe}_{0.01}\right)_{\Sigma 0.94}\left(\mathrm{H}_{2} \mathrm{O}\right)_{6.00}\left[\mathrm{Sb}(\mathrm{OH})_{6}\right]_{2.00}$. The XRD pattern was indexed in a trigonal setting (space group P3), with refined unit-cell parameters $a=16.1076(9), c=9.8628(9) \AA$ and $V=2216.1(2) \AA^{3}$. The thermogravimetric curve shows total weight loss of $34.6 \mathrm{wt}$ \% (over the interval of $20-800{ }^{\circ} \mathrm{C}$ ), caused by $\mathrm{H}_{2} \mathrm{O}$ release. The initial rapid weight decrease $\left(20-140{ }^{\circ} \mathrm{C}\right)$ was followed by a minor continuous weight loss up to $800^{\circ} \mathrm{C}$. Brandholzite from Pernek and its mineral association were probably formed by sub-recent weathering processes in an abandoned mines environment.

Keywords: brandholzite, roméite, supergene mineral association, Pernek, Slovak Republic

Received: 10 December 2009; accepted: 24 May 2010; handling editor: F. Laufek

\section{Introduction}

The rare mineral brandholzite, trigonal $\mathrm{MgSb}_{2}(\mathrm{OH})_{12} \cdot 6 \mathrm{H}_{2} \mathrm{O}$, was originally described by Friedrich et al. (2000) as colourless plate-like crystals up to $1 \mathrm{~mm}$ across in association with stibnite and antimony-ochres from the former Brandholz-Goldkronach mining area, Fichtelgebirge (Germany). It formed there most probably as an alteration product of stibnite within a supergene zone. The study of crystal structure of brandholzite and its synthetic analogue has been published by the same authors; it is isotypic with bottinoite and synthetic $\mathrm{Co}\left(\mathrm{H}_{2} \mathrm{O}\right)_{6}\left[\mathrm{Sb}(\mathrm{OH})_{6}\right]_{2}$ (Bonazzi and Mazzi 1996; Friedrich et al. 2000, 2003).

In addition to the study of the mineral association schafarzikite-valentinite-kermesite-sénarmontite (Sejkora et al. 2007), based on samples collected during the period 2002-2003 at the Krížnica locality (Pernek, Slovak Republic), rare samples with minute crystals of brandholzite were noted (Sejkora et al. 2004). Later on, additional samples were collected, carrying more abundant brandholzite crystals and crystal crusts. This paper presents data obtained by the study of these newly collected samples. Results from spectroscopic study on brandholzite from Pernek were published by Frost et al. (2009). Besides the original brandholzite occurrence at Brandholz, Germany, Fillela et al. (2009) mentioned the brandholzite finds at abandoned antimony mine in Goesdorf, Luxembourg. The new finds at Pernek thus represent a third locality for which mineralogical data are published. This paper is a part of our systematic research concerned with a large group of minerals from various types of supergene zones and occurrences (Plášil et al. 2009a-c, Sejkora et al. 2009a-b).

\section{Geological setting}

The abandoned Sb deposit Pernek-Krížnica is situated about $3 \mathrm{~km}$ west of the village of Pernek (Fig. 1), on the eastern slopes of the Krížnica hill $(604 \mathrm{~m})$ in the Malé Karpaty Mountains (Slovak Republic). The Malé Karpaty Mts. is the westernmost mountain range of the Western Carpathians. The Malé Karpaty Mountains are built by the pre-Alpine basement, its Mesozoic cover, 


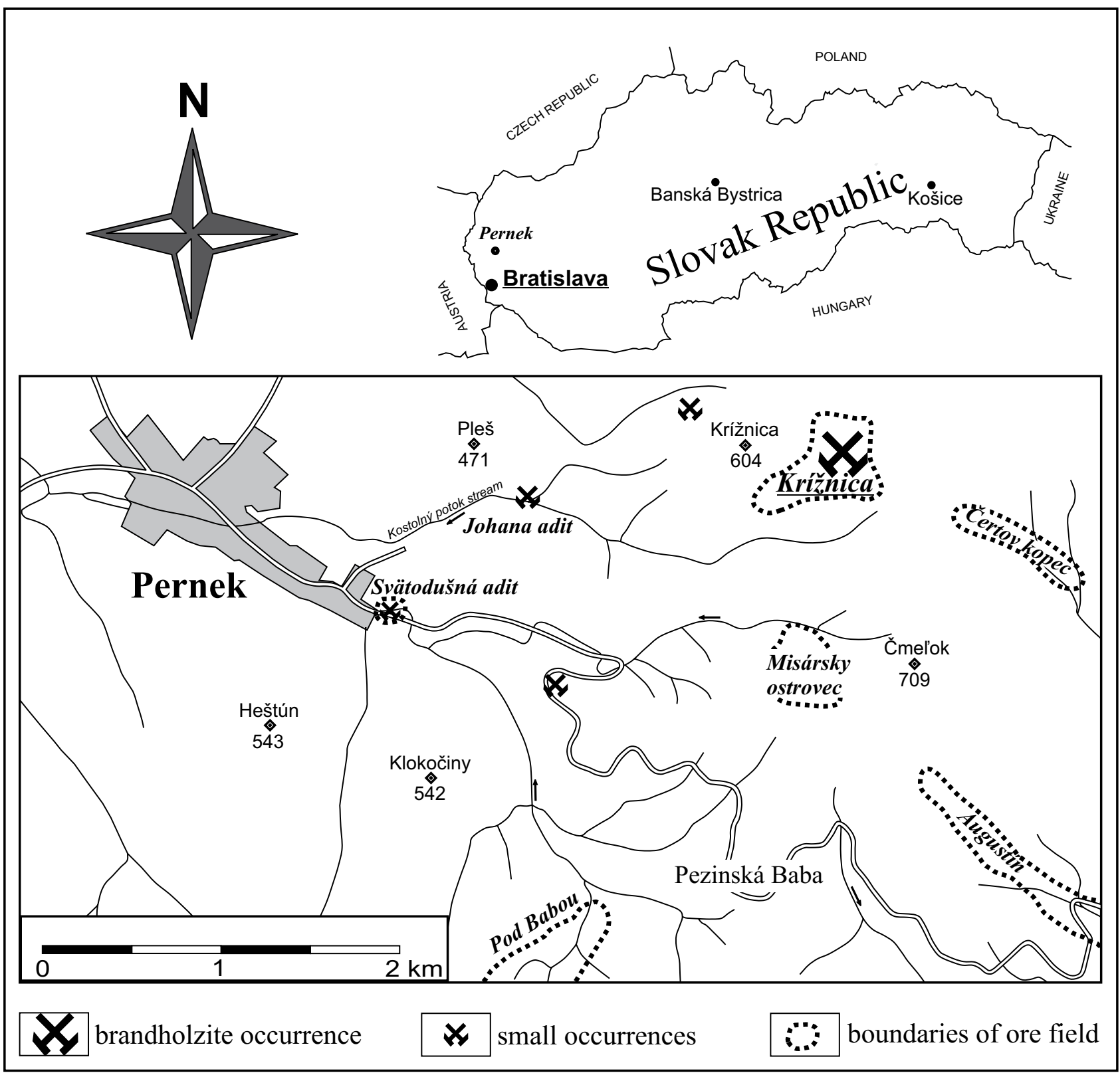

Fig. 1 Map showing the location of abandoned Sb mines in the vicinity of the village of Pernek (Malé Karpaty Mountains, Slovak Republic).

and topmost nappe complexes (Plašienka et al. 1991). The Pre-Alpine Tatric basement consists of two important lithological associations: Pernek and Pezinok groups. Metamorphosed incomplete ophiolite sequence of the Pernek Group (a metagabbro-dolerite dated at $371 \pm$ $4 \mathrm{Ma}$ ) is an analogue to island-arc tholeiites and back-arc basin basalts (Putiš et al 2009). Metabasites of the Pernek Group incorporated into Pernek Nappe (Putiš et al. 2004) considered Ivan et al. (2001) as a relic of upper part of the oceanic crust composed of deep-water sediments, basalts, gabbros and gabbroic differentiates. Pezinok Group is built by clastic metasedimentary rocks (with pelites predominating over psammites) that enclose small bodies of basalts with related tuffs and metacarbonates. This group of Silurian-Devonian age represents a part of rift basin fill probably inboard of an ensialic island arc (Plašienka et al. 1991; Ivan et al. 2001).

The both groups are distinguished not only on the basis of their lithology, but also by their spatial relations with the two large granitoid bodies - the Bratislava and Modra granitoid massifs (Chovan et al. 1992). The age of the earliest metamorphic event in the Pezinok-Pernek Crystalline Complex was estimated at $380 \pm 20 \mathrm{Ma}$ (Cambel et al. 1990). Rb-Sr whole-rock isochron for 


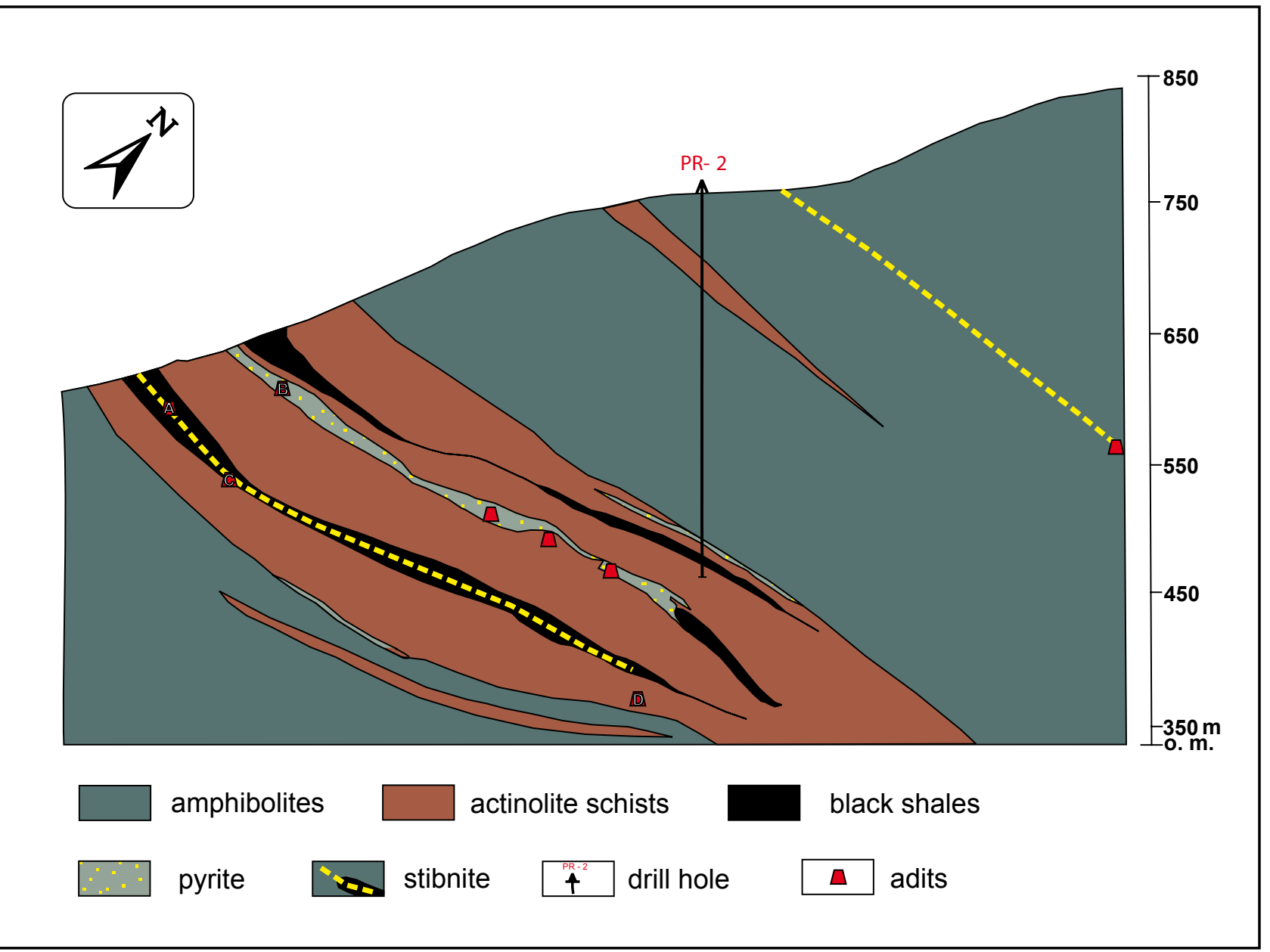

Fig. 2 Cross-section of the Sb deposit Pernek-Krížnica (Žákovský in Cambel 1959; modified by Ozdín).

granitoid rocks from the Malé Karpaty Mts. gave an age of $348 \pm 4 \mathrm{Ma}$ (Cambel et al. 1990). New SHRIMP U$\mathrm{Th}-\mathrm{Pb}$ zircon dating of Bratislava granodiorite yielded $355 \pm 5 \mathrm{Ma}$ and tonalite from Modra $347 \pm 4 \mathrm{Ma}$ (Kohút et al. 2009). Late Paleozoic clastic sediments and basic volcanic rocks, especially basalts, are divided into the Upper Carboniferous Nižná Boca and Permian Maluzina formations (Vozárová and Vozár 1988). The Hercynian tectono-metamorphic events commenced with (1) regional metamorphism and orogenesis, followed by (2) intrusion of Bratislava Granitoid Massif and contact metamorphism, (3) intrusion of Modra Granitoid Massif and establishment of tectonic contact along the Pernek and Harmónia series, and (4) Late Hercynian transport of Pezinok Group toward the Pernek and Harmónia series (Putiš 1987; Plašienka et al. 1991).

Pernek is old Slovak antimony deposit, which has been mined, with short breaks, from the end of $18^{\text {th }}$ century till 1922. Final exploration took place in 1952-1956. The ore mineralization at the Pernek-Krížnica deposit is associated with carbonaceous shales and phyllites in a zone of actinolitic metamorphic rocks, belonging to the Pernek Group. Krusch (1916) stated that the Pernek deposit consists of one major, one minor, and two smaller veins. However, Cambel (1959) observed that the stibnite ores are not located in veins but in stockworks and irregular nests in carbonaceous shales. The mineralized stockworks contain abundant quartz and carbonates and their thickness varies between 0.5 and $1.0 \mathrm{~m}$, rarely up to $4.0 \mathrm{~m}$ (Fig. 2). The stibnite-bearing stockworks strike NW-SE, dip $40-60^{\circ}$ to NE and are heavily sheared and brecciated. Hydrothermal alteration is responsible for occurrence of abundant quartz, carbonates, pyrite, and chlorite in rocks that host the mineralized stockworks (Cambel 1959; Čillík et al. 1959).

Cambel (1959) distinguished three stages of ore formation at the Pernek deposit: (1) quartz-pyrite-arsenopyrite stage, (2) stibnite-carbonate-quartz stage, and (3) stibnite-kermesite stage. According to a survey of pre-1980 literature (Koděra et al. 1990) the primary minerals de- 
scribed from the Pernek deposit are ankerite, antimony, aragonite, arsenopyrite, berthierite, boulangerite (?), calcite, dolomite, galena, glaucodot (?), gold, gudmundite, chalcopyrite, jamesonite (?), kermesite, muscovite var. fuchsite, pyrite, quartz, sénarmontite, sphalerite, scheelite, stibnite and valentinite. Supergene minerals known from this deposit are azurite, cervantite, kermesite, malachite, sénarmontite, schafarzikite, valentinite, unidentified sulphates, iron oxides and hydroxides, as well as Sb-ochres. Sejkora et al. (2007) published a description of the newly found primary schafarzikite-valentinite-kermesite-sénarmontite mineral association. This association is comparable with stibnite-kermesite-valentinite assemblage published by Cambel (1959). The hitherto obtained data indicate a crystallization of the assemblage from late oxidizing hydrothermal fluids, i.e., not as a weathering product. Pernek deposit is also known as type locality of a mineral schafarzikite (Krenner 1921).

\section{Analytical techniques}

The surface morphology of samples was studied with the optical microscope Nikon SMZ1500 in combination with the digital camera Nikon DXM1200F, used for photography in incandescent light.

The X-ray powder diffraction patterns were obtained from handpicked mineral samples using HZG4-AREM/ Seifert diffractometer $\left(50 \mathrm{kV} / 40 \mathrm{~mA} ; \mathrm{CuK}_{\alpha}\right.$ radiation). To minimize the complicated shape of background due to classic glass sample holder, the samples were placed onto a flat silicon wafer from alcoholic suspension. For unit-cell parameters step-scanned $\left(0.05^{\circ} / 6 \mathrm{~s}\right)$ powder $\mathrm{X}$-ray diffraction pattern of brandholzite was collected in the range $7-78^{\circ}(2 \theta)$. Positions and intensities of reflections were calculated using the Pearson VII profile shape function by ZDS program package (Ondruš 1993). The measured patterns were indexed by data calculated (Lazy Pulverix program - Yvon et al. 1977) from published crystal structure information on brandholzite (Friedrich et al. 2000); unit cell parameters were refined by program of Burnham (1962) from all collected data.

Quantitative chemical analyses of brandholzite were carried out by means of electron microprobe Cameca SX 100 (State Geological Institute of Dionýz Štúr, Bratislava) in wavelength dispersive mode (acceleration voltage $15 \mathrm{kV}$, sample current $15 \mathrm{nA}$ and beam diameter of $0.70-50 \mu \mathrm{m})$. The standards and wavelengths used were: $\mathrm{MgO}$ synth. $\left(\mathrm{Mg} \mathrm{K}_{\alpha}\right)$, wollastonite $\left(\mathrm{Ca} \mathrm{K}_{\alpha}\right)$, hematite $\left(\mathrm{Fe} \mathrm{K}{ }_{\alpha}\right)$ and $\mathrm{Sb}_{2} \mathrm{~S}_{3}\left(\mathrm{Sb} \mathrm{L}_{\beta}\right)$. Possible presence of additional elements with $Z>6$ was checked by detailed WD scans, which yielded negative results.

Chemical data for other mineral phases were collected with the electron microprobe Cameca SX 100
(Laboratory of Electron Microscopy and Microanalysis the Masaryk University in Brno) operating in the wavelength-dispersion mode with an accelerating voltage of $15 \mathrm{kV}$, a sample current of $10 \mathrm{nA}$, and a beam diameter of 3-5 $\mu \mathrm{m}$. The following lines and standards were used: $\mathrm{K}_{a}$ : andradite $(\mathrm{Fe})$, albite $(\mathrm{Na}), \mathrm{ZnS}(\mathrm{S})$, sanidine (Al, $\mathrm{Si}, \mathrm{K})$, fluorapatite $(\mathrm{Ca})$, pyrope $(\mathrm{Mg})$, vanadinite $(\mathrm{V})$, topaz (F), halite $(\mathrm{Cl}) ; \mathrm{L}_{\alpha}$ : InAs (As), $\mathrm{Cu}(\mathrm{Cu}), \mathrm{Sb}(\mathrm{Sb})$; $\mathrm{M}_{\alpha}: \mathrm{PbSe}(\mathrm{Pb})$ and $\mathrm{M}_{\beta}: \mathrm{Bi}(\mathrm{Bi})$. Peak counting times were $20 \mathrm{~s}$ for main elements and $60 \mathrm{~s}$ for minor elements. For each background, they were set at $1 / 2$ of peak time. Raw intensities were converted to the concentrations using automatic PAP (Pouchou and Pichoir 1985) matrix correction software package. Contents of the above listed elements, which are not included in tables of analyses, were determined, but the measured values were below respective detection limits (c. 0.01-0.04 wt. \%).

Thermogravimetric analysis was carried out with a Stanton Redcroft TG 750 Thermobalance. The sample (weight $1.99 \mathrm{mg}$ ) was heated from room temperature to $950{ }^{\circ} \mathrm{C}$ at a heating rate of $10{ }^{\circ} \mathrm{C} \cdot \mathrm{min}^{-1}$ in flowing air $\left(10 \mathrm{ml} \cdot \mathrm{min}^{-1}\right)$.

\section{Results and discussion}

\subsection{Brandholzite}

\subsubsection{Description of samples}

Brandholzite and associated minerals occur on surface and along fractures of dark grey rocks (hydrothermally altered shales) collected as fragments up to $12 \mathrm{~cm}$ long and mineralized by quartz, fine-grained stibnite and pyrite. Brandholzite forms isolated, translucent to transparent tabular crystals, usually $0.5-1.2 \mathrm{~mm}$ long.

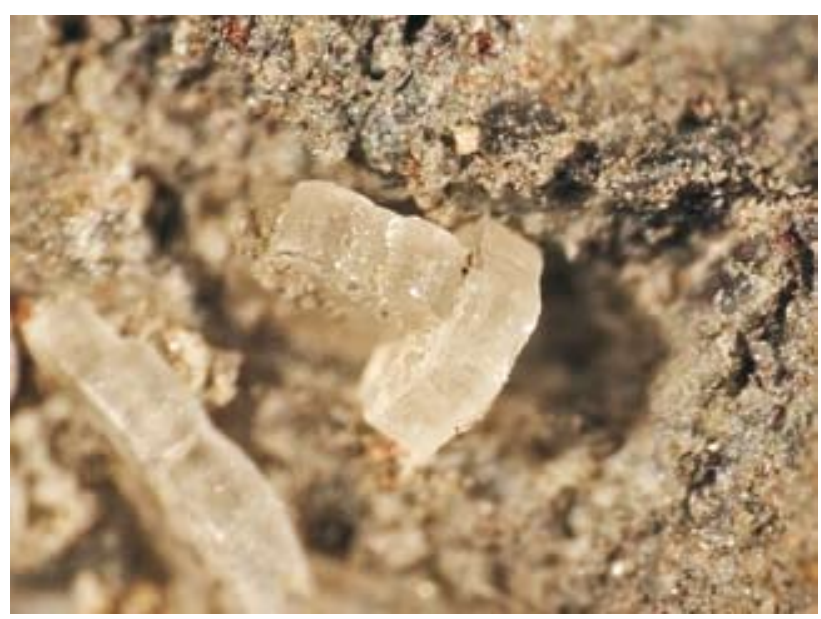

Fig. 3 Tabular crystals of brandholzite with a distinctive hexagonal habit. Width of the area $2 \mathrm{~mm}$. Photo J. Sejkora. 
The crystals of hexagonal habit (Fig. 3), frequently with white clouding, are often grouped in inconspicuous white coatings (Fig. 4) up to several $\mathrm{cm}^{2}$ in size. The crystals exhibit a characteristic striation of prismatic faces. They are very brittle, without cleavage; they show conchoidal fracture, vitreous lustre and white streak. No fluorescence was observed under either short- or long-wave UV radiation. Brandholzite crystals are rarely overgrown by younger sénarmontite. Gypsum, roméite-like mineral phases, sulphur, aragonite and Sb-rich Fe-hydroxides can be closely associated with brandholzite. Some specimens contain evidently older minerals, such as acicular stibnite, abundant aggregates of red kermesite and radiating clusters of white valentinite.

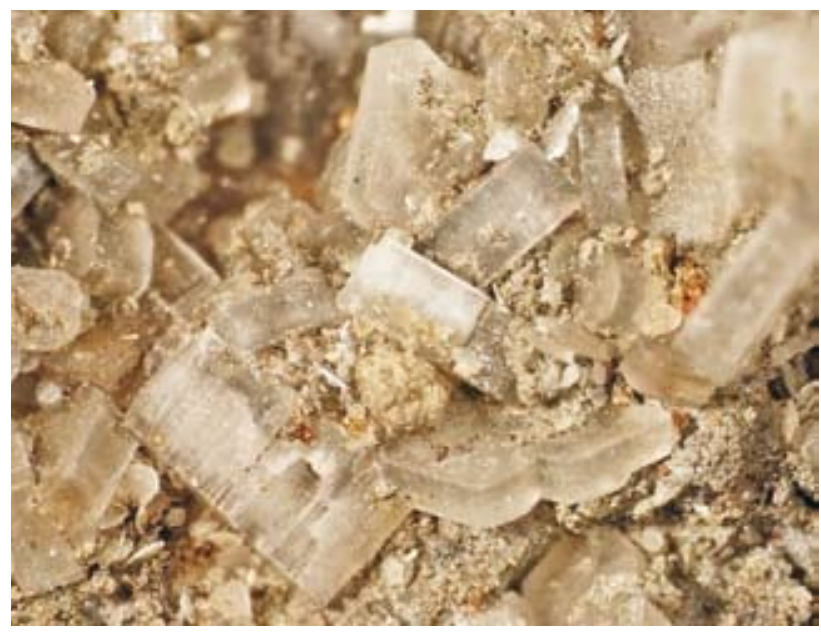

Fig. 4 A random aggregate of tabular crystals of brandholzite. Width of the area $3 \mathrm{~mm}$. Photo J. Sejkora.

\subsubsection{Chemical composition}

Brandholzite from Pernek is unstable under the electron beam. Detected contents of elements are higher than the theoretical ones. A similar experience was reported by Friedrich et al. (2000) for brandholzite from the type locality. To overcome these problems we used varied electron beam diameter up to $50 \mu \mathrm{m}$ in course of the microprobe analysis. These trial tests indicated dependency of analytical total on the beam diameter (Fig. 5). Hence, all analyses were recalculated to $100 \mathrm{wt}$. \% including $\mathrm{H}_{2} \mathrm{O}$ amount indicated by the ideal formula (Tab. 1).

The average empirical formula of brandholzite calculated from eight analyses obtained with various beam diameters $(0.70-50 \mu \mathrm{m})$ on the basis of $\mathrm{Sb}=2$ apfu is $\left(\mathrm{Mg}_{0.82} \mathrm{Ca}_{0.03} \mathrm{Fe}_{0.01}\right)_{\Sigma 0.86}\left(\mathrm{H}_{2} \mathrm{O}\right)_{6.00}\left[\mathrm{Sb}(\mathrm{OH})_{6}\right]_{2.00}$. In this case, the $\mathrm{M}^{2+} / \mathrm{Sb}$ ratio varies in the range $0.347-0.480$. Two analyses obtained with beam diameter $50 \mu \mathrm{m}$ (i.e., least influenced by evaporation under the electron beam) yield empirical formula $\left(\mathrm{Mg}_{0.88} \mathrm{Ca}_{0.05} \mathrm{Fe}_{0.01}\right)_{\Sigma 0.94}$

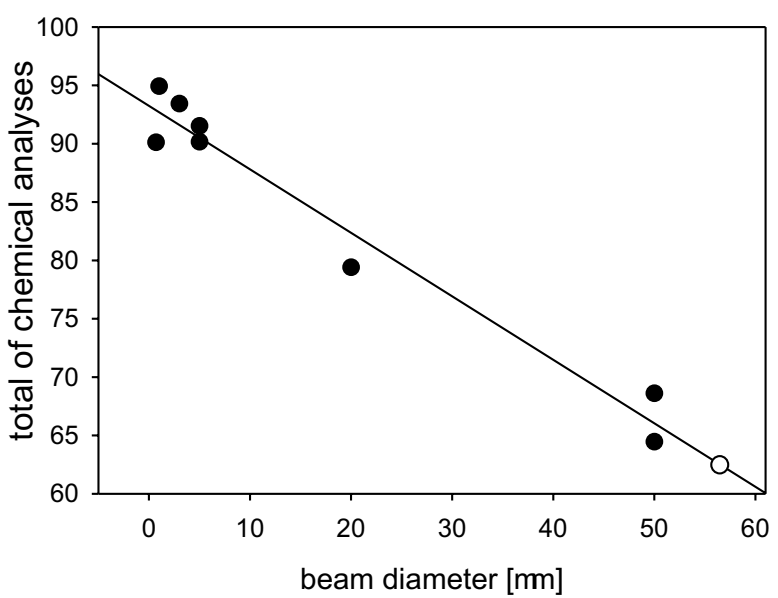

Fig. 5 Relation of analytical totals to beam diameter (black circles); white circle corresponds to the total of atoms in the ideal formula plotted on the regression line fitted through the experimental data.

$\left(\mathrm{H}_{2} \mathrm{O}\right)_{6.00}\left[\mathrm{Sb}(\mathrm{OH})_{6}\right]_{2.00}$, characterised by $\mathrm{M}^{2+} / \mathrm{Sb}$ ratio in the range $0.465-0.480$. The $\mathrm{M}^{2+} / \mathrm{Sb}$ ratios lower than the theoretical value of 0.500 were reported by Friedrich et al. (2000) for natural and synthetic brandholzite (Tab. 2).

Antimony necessary for crystallization of brandholzite was most probably derived by weathering of primary stibnite under conditions of oxidation and hydration. Magnesium was released by supergene alteration of Mg-rich ankerite via action of acidic solutions. Brandholzite probably acted as a selective repository of $\mathrm{Mg}$ present in solutions, as no other supergene mineral with noteworthy $\mathrm{Mg}$ contents has been found in the association. The coexisting roméite-like phases contain only low amounts of Mg.

\subsubsection{X-ray powder diffraction}

The X-ray powder diffraction pattern of brandholzite from Pernek (Tab. 3) closely corresponds to data published for synthetic $\mathrm{Mg}\left(\mathrm{H}_{2} \mathrm{O}\right)_{6}\left[\mathrm{Sb}(\mathrm{OH})_{6}\right]_{2}$ and data calculated from the crystal structure (Friedrich et al. 2000) of natural brandholzite. Owing to the rarity of natural brandholzite at Brandholz, only incomplete powder X-ray data have been available so far (Friedrich et al. 2000). The refined unit-cell parameters of the studied brandholzite (Tab. 4) are in very good agreement with parameters reported for brandholzite from the type locality and for synthetic material.

\subsubsection{Thermogravimetric data}

Friedrich et al. (2000) reported results of thermal decomposition of synthetic $\mathrm{Mg}\left(\mathrm{H}_{2} \mathrm{O}\right)_{6}\left[\mathrm{Sb}(\mathrm{OH})_{6}\right]_{2}$, however the thermogravimetric curve was not included in his paper. 
Tab. 1 Chemical composition of brandholzite (wt. \%)

\begin{tabular}{|c|c|c|c|c|c|c|c|c|c|c|}
\hline & Mean $^{\mathrm{a}}$ & Mean $^{\mathrm{b}}$ & 1 & 2 & 3 & 4 & 5 & 6 & 7 & 8 \\
\hline $\mathrm{CaO}$ & 0.52 & 0.26 & 0.07 & 0.49 & 0.15 & 0.04 & 0.09 & 0.20 & 0.34 & 0.71 \\
\hline $\mathrm{FeO}$ & 0.16 & 0.08 & 0.07 & 0.04 & 0.02 & 0.10 & 0.01 & 0.07 & 0.18 & 0.14 \\
\hline $\mathrm{MgO}$ & 6.11 & 5.77 & 5.93 & 4.56 & 5.63 & 5.96 & 5.89 & 5.97 & 6.15 & 6.08 \\
\hline $\mathrm{Sb}_{2} \mathrm{O}_{5}$ & 55.89 & 56.36 & 56.39 & 57.08 & 56.58 & 56.38 & 56.45 & 56.27 & 55.97 & 55.78 \\
\hline $\mathrm{H}_{2} \mathrm{O}$ & 37.32 & 37.53 & 37.54 & 37.83 & 37.62 & 37.53 & 37.57 & 37.49 & 37.36 & 37.29 \\
\hline Sum & 100.00 & 100.00 & 100.00 & 100.00 & 100.00 & 100.00 & 100.00 & 100.00 & 100.00 & 100.00 \\
\hline Total $^{c}$ & & & 86.45 & 81.93 & 85.04 & 83.35 & 82.10 & 72.33 & 62.54 & 58.79 \\
\hline Beam $^{\mathrm{d}}$ & & & 1 & 1 & 3 & 5 & 5 & 20 & 50 & 50 \\
\hline $\mathrm{Ca}^{2+}$ & 0.054 & 0.027 & 0.007 & 0.049 & 0.016 & 0.004 & 0.009 & 0.021 & 0.035 & 0.074 \\
\hline $\mathrm{Fe}^{2+}$ & 0.013 & 0.006 & 0.006 & 0.003 & 0.002 & 0.008 & 0.001 & 0.006 & 0.015 & 0.012 \\
\hline $\mathrm{Mg}^{2+}$ & 0.878 & 0.821 & 0.844 & 0.642 & 0.798 & $0 \ldots 848$ & 0.837 & 0.851 & 0.881 & 0.874 \\
\hline$\Sigma \mathrm{M}^{2+}$ & 0.945 & 0.854 & 0.857 & 0.694 & 0.816 & 0.860 & 0.847 & 0.878 & 0.931 & 0.959 \\
\hline $\mathrm{Sb}^{5+}$ & 2.000 & 2.000 & 2.000 & 2.000 & 2.000 & 2.000 & 2.000 & 2.000 & 2.000 & 2.000 \\
\hline $\mathrm{H}^{+}$ & 23.999 & 23.999 & 23.997 & 24.001 & 24.001 & 23.997 & 24.004 & 23.999 & 23.996 & 24.001 \\
\hline
\end{tabular}

The point analyses and their means recalculated to $100 \mathrm{wt} \%$ after addition of $\mathrm{H}_{2} \mathrm{O}$ amount indicated by the ideal formula; coefficients of empirical formulae were calculated setting $\mathrm{Sb}=2$ apfu.

${ }^{a}$ mean of two point analyses (7-8)

${ }^{\mathrm{b}}$ mean of all 8 point analyses $(1-8)$

c experimental totals of analyses

d beam diameter $[\mu \mathrm{m}]$

The sample of brandholzite from Pernek used for thermogravimetric study shows a white internal clouding. The thermogravimetric curve is presented in Fig. 6. This specimen thermally decomposed in two principal steps. In the first step $\left(20-140^{\circ} \mathrm{C}\right)$, the weight decreased dramatically by $24.0 \mathrm{wt}$. \%, corresponding to $c .8 \mathrm{H}_{2} \mathrm{O}$ molecules. In the second step $\left(140-800{ }^{\circ} \mathrm{C}\right)$, a minor continuous loss of the weight, equivalent to $10.6 \mathrm{wt}$. \%, and corresponding to $c .3 .5 \mathrm{H}_{2} \mathrm{O}$ molecules, took place. The total weight loss over the temperature interval of $20-800{ }^{\circ} \mathrm{C}$ was 34.6 wt. \%. This value is somewhat lower than the theoretical content of 37.3 wt. $\% \mathrm{H}_{2} \mathrm{O}$, which is probably due to

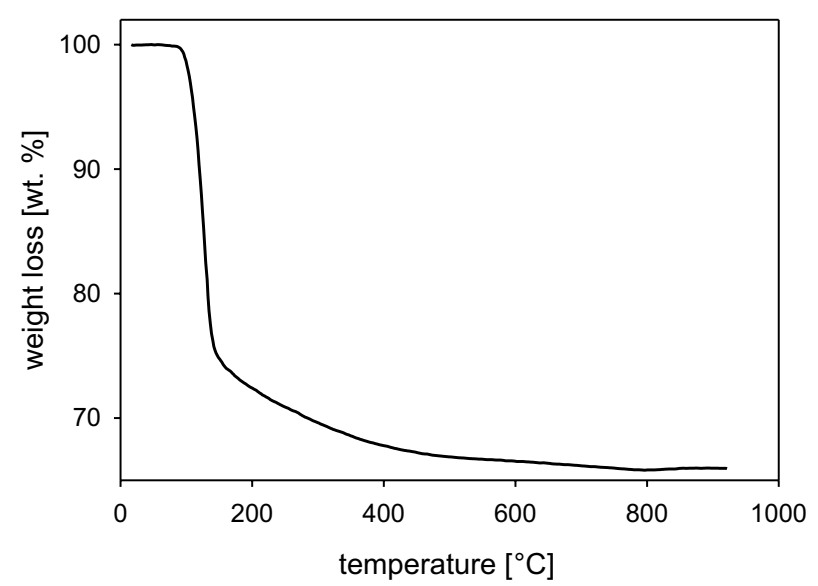

Fig. 6 Thermogravimetric curve for brandholzite from Pernek.
Tab. $2 \mathrm{M}^{2+} / \mathrm{Sb}$ ratios in natural and synthetic samples of brandholzite

\begin{tabular}{lll}
\hline & & $\mathrm{M}^{2+} / \mathrm{Sb}$ \\
\hline Pernek & this paper & $0.427(0.347-0.480)$ \\
Brandholz & Friedrich et al. (2000) & 0.465 \\
synthetic & Friedrich et al. (2000) & 0.416 \\
theoretical & & 0.500
\end{tabular}

a slight dehydration of the brandholzite sample used in the thermogravimetric experiment. Friedrich et al. (2000) reported a total weight loss of $39.0 \mathrm{wt}$ \% for synthetic $\mathrm{Mg}\left(\mathrm{H}_{2} \mathrm{O}\right)_{6}\left[\mathrm{Sb}(\mathrm{OH})_{6}\right]_{2}$.

\subsection{Other minerals identified in the association}

\subsubsection{Roméite-like phases}

Minerals of the roméite group occur in the studied samples as two varieties of distinctive colour and chemical composition. The early white roméite forms coatings up to $20 \mu \mathrm{m}$ thick with uneven surfaces, deposited on acicular stibnite crystals (Fig. 7). It is non-transparent and exhibits a weak lustre. Yellow roméite forms irregular to botryoidal or porous aggregates $1-2 \mathrm{~mm}$ in size, deposited along fractures. It probably represents imperfect pseudomorphs after crystals and aggregates of primary Mg-rich ankerite. These aggregates are not transparent, yellow, creamy, ochre or brown in colour, with a weak lustre. The X-ray powder patterns of both 
Tab. 3 X-ray powder diffraction pattern for brandholzite from Pernek

\begin{tabular}{|c|c|c|c|c|c|c|c|c|c|c|c|c|c|c|c|c|c|}
\hline$h$ & $k$ & $l$ & $d_{o b s .}$ & $I / I_{o}$ & $d_{\text {calc. }}$ & $h$ & $k$ & $l$ & $d_{o b s .}$ & $I / I_{o}$ & $d_{\text {calc. }}$ & $h$ & $k$ & $l$ & $d_{o b s .}$ & $I / I_{o}$ & $d_{\text {calc. }}$ \\
\hline 0 & 0 & 1 & 9.871 & 8 & 9.863 & 1 & 5 & 2 & 2.234 & 6 & 2.234 & 6 & 0 & 5 & 1.5041 & 4 & 1.5041 \\
\hline 1 & 1 & 0 & 8.091 & 7 & 8.054 & 5 & 1 & 2 & & & 2.234 & 0 & 6 & 5 & & & 1.5041 \\
\hline 1 & 1 & 1 & 6.230 & 8 & 6.238 & 1 & 2 & 4 & & & 2.234 & 9 & 0 & 2 & 1.4787 & 8 & 1.4786 \\
\hline 1 & 1 & -1 & & & 6.238 & 2 & 1 & 4 & & & 2.234 & 0 & 9 & 2 & & & 1.4786 \\
\hline 0 & 0 & 2 & 4.935 & 21 & 4.931 & 0 & 3 & 4 & 2.179 & 8 & 2.178 & 4 & 1 & -6 & 1.4469 & 3 & 1.4464 \\
\hline 3 & 0 & 0 & 4.650 & 100 & 4.650 & 3 & 0 & 4 & & & 2.178 & 1 & 4 & 6 & & & 1.4464 \\
\hline 3 & 0 & 1 & 4.208 & 18 & 4.206 & 6 & 0 & 2 & 2.103 & 14 & 2.103 & 4 & 1 & 6 & & & 1.4464 \\
\hline 0 & 3 & 1 & & & 4.206 & 0 & 6 & 2 & & & 2.103 & 6 & 3 & -4 & 1.4309 & 5 & 1.4312 \\
\hline 2 & 2 & 0 & 4.033 & 9 & 4.027 & 3 & 3 & -3 & 2.080 & 7 & 2.079 & 6 & 3 & 4 & & & 1.4312 \\
\hline 2 & 0 & 2 & & & 4.027 & 5 & 2 & 2 & 2.035 & 5 & 2.035 & 3 & 6 & 4 & & & 1.4312 \\
\hline 0 & 2 & 2 & & & 4.027 & 3 & 2 & 4 & 1.9543 & 6 & 1.9532 & 3 & 6 & -4 & & & 1.4312 \\
\hline 2 & 2 & -1 & 3.728 & 5 & 3.728 & 3 & 2 & -4 & & & 1.9532 & 0 & 9 & 3 & 1.4015 & 4 & 1.4020 \\
\hline 2 & 2 & 1 & & & 3.728 & 2 & 3 & 4 & & & 1.9532 & 9 & 0 & 3 & & & 1.4020 \\
\hline 1 & 2 & 2 & 3.606 & 5 & 3.602 & 2 & 3 & -4 & & & 1.9532 & 3 & 3 & -6 & & & 1.4019 \\
\hline 2 & 1 & 2 & & & 3.602 & 5 & 2 & -3 & 1.8475 & 5 & 1.8476 & 3 & 3 & 6 & & & 1.4019 \\
\hline 0 & 3 & 2 & 3.383 & 40 & 3.383 & 5 & 0 & 4 & & & 1.8476 & 6 & 6 & 0 & 1.3425 & 7 & 1.3423 \\
\hline 3 & 0 & 2 & & & 3.383 & 0 & 5 & 4 & & & 1.8476 & 6 & 0 & 6 & & & 1.3422 \\
\hline 2 & 2 & 2 & 3.119 & 3 & 3.119 & 3 & 3 & 4 & 1.8156 & 16 & 1.8160 & 0 & 6 & 6 & & & 1.3422 \\
\hline 2 & 2 & -2 & & & 3.119 & 3 & 3 & -4 & & & 1.8160 & 5 & 2 & -6 & 1.3238 & 5 & 1.3240 \\
\hline 1 & 4 & 0 & 3.043 & 7 & 3.044 & 4 & 2 & 4 & 1.7985 & 4 & 1.8008 & 2 & 5 & 6 & & & 1.3240 \\
\hline 4 & 1 & 0 & & & 3.044 & 2 & 4 & 4 & & & 1.8008 & 2 & 5 & -6 & & & 1.3240 \\
\hline 1 & 1 & 3 & & & 3.044 & 6 & 3 & 0 & 1.7570 & 22 & 1.7575 & 9 & 0 & 4 & 1.3124 & 4 & 1.3122 \\
\hline 1 & 4 & 1 & 2.911 & 6 & 2.909 & 3 & 6 & 0 & & & 1.7575 & 0 & 9 & 4 & & & 1.3122 \\
\hline 3 & 3 & 0 & 2.685 & 14 & 2.685 & 3 & 6 & -1 & 1.7303 & 8 & 1.7302 & 6 & 6 & 2 & 1.2958 & 5 & 1.2952 \\
\hline 0 & 3 & 3 & & & 2.684 & 6 & 3 & -1 & & & 1.7302 & 6 & 6 & -2 & & & 1.2952 \\
\hline 3 & 0 & 3 & & & 2.684 & 6 & 0 & 4 & 1.6901 & 8 & 1.6916 & 9 & 3 & 0 & 1.2895 & 7 & 1.2896 \\
\hline 3 & 3 & -1 & 2.590 & 20 & 2.590 & 0 & 6 & 4 & & & 1.6916 & 3 & 9 & 0 & & & 1.2896 \\
\hline 1 & 4 & -2 & & & 2.590 & 6 & 3 & -2 & 1.6555 & 14 & 1.6555 & 9 & 3 & 2 & 1.2480 & 6 & 1.2477 \\
\hline 4 & 1 & -2 & & & 2.590 & 6 & 3 & 2 & & & 1.6555 & 3 & 9 & 2 & & & 1.2477 \\
\hline 1 & 4 & 2 & & & 2.590 & 3 & 6 & 2 & & & 1.6555 & 3 & 9 & -2 & & & 1.2477 \\
\hline 0 & 5 & 2 & 2.428 & 5 & 2.428 & 3 & 6 & -2 & & & 1.6555 & 9 & 3 & -2 & & & 1.2477 \\
\hline 5 & 0 & 2 & & & 2.428 & 1 & 6 & -4 & 1.6099 & 7 & 1.6107 & & & & & & \\
\hline 3 & 3 & -2 & 2.358 & 21 & 2.358 & 6 & 1 & -4 & & & 1.6107 & & & & & & \\
\hline 3 & 3 & 2 & & & 2.358 & 9 & 0 & 0 & 1.5500 & 10 & 1.5500 & & & & & & \\
\hline 6 & 0 & 0 & 2.324 & 10 & 2.325 & 0 & 3 & 6 & & & 1.5498 & & & & & & \\
\hline 6 & 0 & 1 & 2.262 & 6 & 2.263 & 3 & 0 & 6 & & & 1.5498 & & & & & & \\
\hline 0 & 6 & 1 & & & 2.263 & & & & & & & & & & & & \\
\hline
\end{tabular}

Tab. 4. Unit-cell parameters for brandholzite (trigonal space group P3)

\begin{tabular}{lllll}
\hline occurrence & reference & $a[\AA]$ & $c[\AA]$ & $V\left[\AA^{3}\right]$ \\
\hline Pernek & this paper & $16.1076(9)$ & $9.8628(9)$ & $2216.1(2)$ \\
Brandholz & Friedrich et al. (2000) & $16.119(1)$ & $9.868(1)$ & 2220.4 \\
synthetic & Friedrich et al. (2000) & $16.113(1)$ & $9.868(1)$ & 2218.8 \\
\hline
\end{tabular}




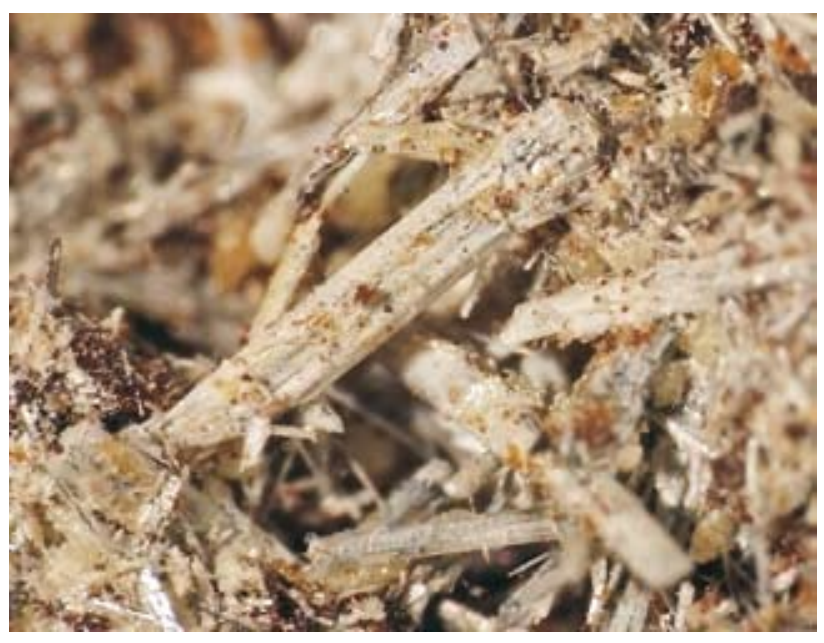

Fig. 7 Coating of white roméite on acicular crystals of stibnite. Width of the area $2 \mathrm{~mm}$. Photo J. Sejkora.

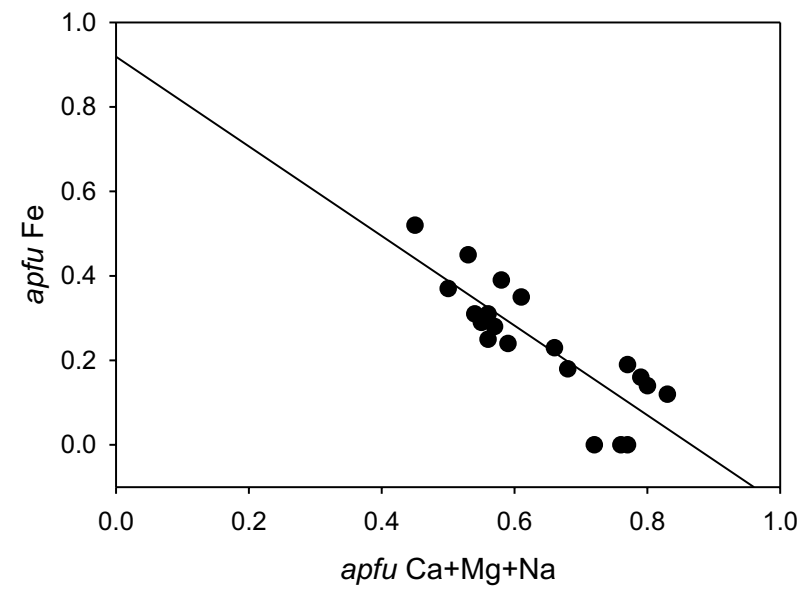

Fig. 8 Regression line for correlation Fe vs. $\mathrm{Ca}+\mathrm{Mg}+\mathrm{Na}(a p f u)$ in $A$-site of the roméite-like minerals from Pernek.

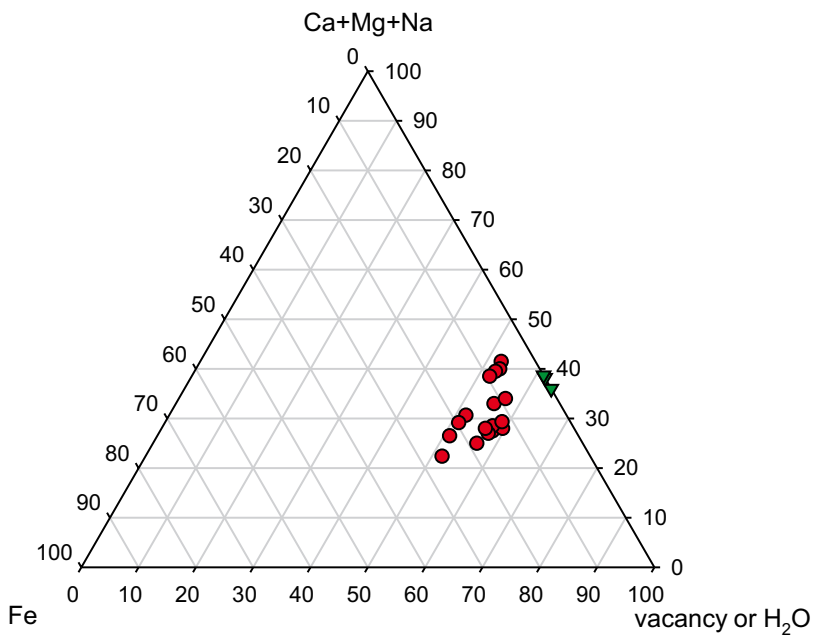

Fig. 9 Occupancy of $A$-site in roméite-like minerals from Pernek (green symbols: white, red symbols: yellow roméite). roméite types indicate a high proportion of an amorphous phase and include several diffraction maxima of subdued intensity and increased half-width value. The diffractions correspond to the unit-cell of cubic roméite.

Roméite-like minerals are structurally related to pyrochlore-group minerals with a general chemical formula $\mathrm{A}_{2-\mathrm{m}} \mathrm{B}_{2} \mathrm{X}_{6-\mathrm{w}} \mathrm{Y}_{1-\mathrm{n}} \cdot \mathrm{pH}_{2} \mathrm{O}$ (Brugger et al. 1997). $A$-site is occupied by $\mathrm{Ca}, \mathrm{Na}, \mathrm{Ba}, \mathrm{Bi}, \mathrm{Sb}, \mathrm{REE}$ and other elements; the value $m$ denotes vacancy or $\mathrm{H}_{2} \mathrm{O}$ content, which are both common in these minerals (Brugger et al. 1997). $B$-site in roméite-like minerals is occupied mainly by $\mathrm{Sb}^{5+}$, or by subordinate $\mathrm{Ti}^{4+}, \mathrm{W}^{5+}, \mathrm{Fe}^{3+}$ and $\mathrm{Al}^{3+}$. As no vacancy or $\mathrm{H}_{2} \mathrm{O}$ occur in this site, its full occupancy $(=2)$ is used as a basis for recalculation of analyses. $X$-site is usually dominated by $\mathrm{O}^{2-}$, or lower quantities of $\mathrm{F}^{-}$and $\mathrm{OH}^{-}$; a limited vacancy (value $w$ ) is also known. $Y$-site is occupied by $\mathrm{OH}^{-}, \mathrm{F}^{-}$and $\mathrm{O}^{2-}$ accompanied by large monovalent cations (K, Rb, Cs, Tl..."inverse pyrochlore") and also $\mathrm{H}_{2} \mathrm{O}$ groups (value $n$ ).

The chemical composition of white roméite is characterized by dominant vacancy or $\mathrm{H}_{2} \mathrm{O}$ content $(1.22-1.28$ $p f u)$ and high contents of $\mathrm{Ca}(0.72-0.77$ apfu) in the $A$-site. In the $B$-site dominates Sb (1.85-1.89 apfu), accompanied by minor Si and S (Fig. 10).

The study of chemical composition of the yellow roméite resulted in determination of increased $\mathrm{Fe}$ and $\mathrm{Si}$ contents, as yet described only in Sb-dominant $\mathrm{Nb}-\mathrm{Ta}-\mathrm{U}$ pyrochlore from Prašivá, Slovakia (Uher et al. 1998). As indicated by the observed correlation (Fig. 8), Fe enters the $A$-site of the ideal formula. Iron content is in the range of 0.12-0.52 apfu. Calcium contents (0.38-0.79 apfu $\mathrm{Ca}$ ) predominate above $\mathrm{Mg}$ and $\mathrm{Na}$. In the used method of recalculation of chemical analyses, vacancy or $\mathrm{H}_{2} \mathrm{O}$ always prevail in the $A$-site (Fig. 9), with calculated contents of 1.02-1.19 pfu. In the $B$-site dominate $\mathrm{Sb}(0.73-1.42)$ and $\mathrm{Si}(0.47-1.21)$; sulphur content is minor (0.10-0.20 apfu S). Some of the analyses show $\mathrm{Si}$ clearly predominating over $\mathrm{Sb}$ in $B$-site (Fig. 10). Silica contents of similar magnitude have not been reported in the literature. The representative spot analyses of roméite-like minerals from Pernek and their formulae recalculated on the basis $B$-atoms $=2$ are presented in Tab. 5. The low totals of the chemical analyses are due to the porous nature of the samples and the presence of molecular water. Likewise, Brugger et al. (1997) reported a significant content of $\mathrm{H}_{2} \mathrm{O}$, up to $14 \mathrm{wt}$. \% in roméite from Massiac (France).

The imperfect crystalline state and chemical inhomogeneity of the studied aggregates of roméite-like mineral phases indicate their spontaneous formation under conditions of an efficient supply of $\mathrm{Ca}, \mathrm{Fe}, \mathrm{Sb}, \mathrm{Si}$ and $\mathrm{S}$ ions in the environment of stibnite, pyrite, $\mathrm{Mg}$-rich ankerite and rock-forming silicates affected by alteration. 


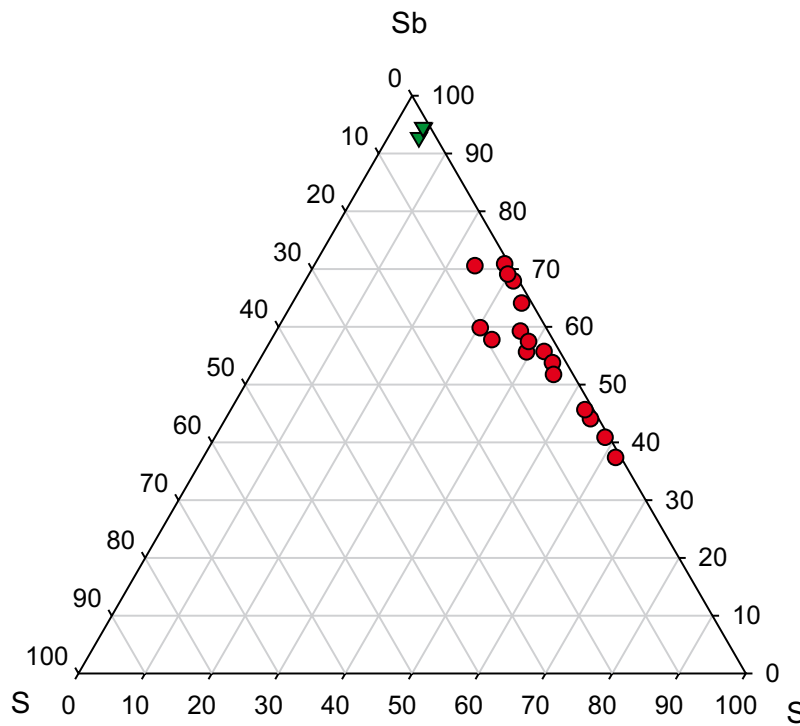

Fig. 10 Occupancy of $B$-site in roméite-like minerals from Pernek (green symbols: white, red symbols: yellow roméite).

\subsubsection{Sulphur}

Native sulphur forms locally abundant oval aggregates up to $1 \mathrm{~mm}$ in diameter (Fig. 11) with corroded surface. The aggregates occur in cavities among acicular stibnite crystals coated by white roméite. The material is transparent, light yellow in colour and exhibits intense greasy

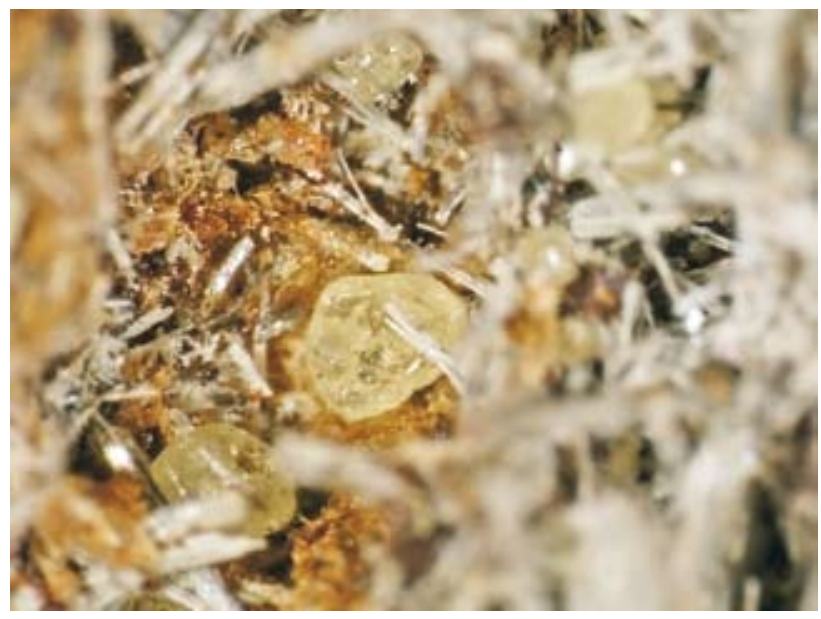

Fig. 11 Yellow aggregates of sulphur among acicular crystals of stibnite coated by white roméite. Width of the area $2 \mathrm{~mm}$. Photo J. Sejkora.

to vitreous lustre. The mineral was identified by X-ray powder diffraction and WD scan, which indicated sulphur as the single element with $\mathrm{Z}>6$.

According to Williams (1990), formation of sulphur under supergene conditions is possible in acidic environment, usually as a transient product, which was not oxidised. The close association with roméite and stibnite indicates that, in addition to the redox influence of $\mathrm{Fe}^{3+} /$ $\mathrm{Fe}^{2+}$, the reaction $\mathrm{Sb}^{3+} / \mathrm{Sb}^{5+}$ probably played a role in the sulphur preservation.

Tab. 5 Chemical composition of roméite-like phases from Pernek (wt. \%)

\begin{tabular}{|c|c|c|c|c|c|c|c|c|c|c|c|c|c|c|c|}
\hline & 1 & 2 & 3 & 4 & 5 & 6 & 7 & 8 & 9 & 10 & 11 & 12 & 13 & 14 & 15 \\
\hline $\mathrm{Na}_{2} \mathrm{O}$ & 0.00 & 0.00 & 0.00 & 0.00 & 0.00 & 0.00 & 0.00 & 0.00 & 0.00 & 0.02 & 0.05 & 0.00 & 0.03 & 0.00 & 0.05 \\
\hline $\mathrm{CaO}$ & 10.75 & 10.73 & 12.90 & 12.77 & 12.12 & 12.25 & 10.29 & 10.10 & 9.82 & 9.43 & 9.66 & 9.59 & 8.86 & 8.42 & 7.10 \\
\hline $\mathrm{FeO}$ & 0.04 & 0.05 & 2.56 & 2.97 & 3.29 & 4.04 & 5.30 & 5.74 & 6.22 & 6.85 & 6.81 & 7.82 & 8.78 & 10.43 & 12.42 \\
\hline $\mathrm{MgO}$ & 0.00 & 0.00 & 0.50 & 0.53 & 0.59 & 0.56 & 0.00 & 0.00 & 0.00 & 0.00 & 0.00 & 0.69 & 0.90 & 0.89 & 0.87 \\
\hline $\mathrm{Al}_{2} \mathrm{O}_{3}$ & 0.00 & 0.00 & 0.00 & 0.00 & 0.00 & 0.00 & 0.36 & 0.42 & 0.41 & 0.54 & 0.51 & 0.56 & 0.58 & 0.64 & 0.80 \\
\hline $\mathrm{SiO}_{2}$ & 1.38 & 1.30 & 9.95 & 11.22 & 10.46 & 12.43 & 11.27 & 12.52 & 13.36 & 14.49 & 14.12 & 15.98 & 16.60 & 20.16 & 24.31 \\
\hline $\mathrm{Sb}_{2} \mathrm{O}_{5}$ & 76.54 & 75.73 & 66.82 & 65.77 & 65.37 & 62.44 & 59.93 & 58.94 & 58.27 & 55.21 & 56.39 & 52.43 & 51.03 & 46.71 & 39.58 \\
\hline $\mathrm{SO}_{3}$ & 0.41 & 0.44 & 0.33 & 0.42 & 0.53 & 0.75 & 4.91 & 4.63 & 2.03 & 2.48 & 1.87 & 1.01 & 1.44 & 0.67 & 0.44 \\
\hline Total & 89.11 & 88.24 & 93.05 & 93.68 & 92.36 & 92.48 & 92.04 & 92.35 & 90.11 & 89.01 & 89.40 & 88.08 & 88.22 & 87.90 & 85.57 \\
\hline $\mathrm{Na}^{+}$ & 0.000 & 0.000 & 0.000 & 0.000 & 0.000 & 0.000 & 0.000 & 0.000 & 0.000 & 0.002 & 0.005 & 0.000 & 0.003 & 0.000 & 0.005 \\
\hline $\mathrm{Ca}^{2+}$ & 0.765 & 0.772 & 0.789 & 0.761 & 0.739 & 0.725 & 0.586 & 0.564 & 0.569 & 0.539 & 0.558 & 0.557 & 0.509 & 0.465 & 0.377 \\
\hline $\mathrm{Fe}^{2+}$ & 0.002 & 0.003 & 0.122 & 0.138 & 0.157 & 0.187 & 0.236 & 0.250 & 0.281 & 0.306 & 0.307 & 0.355 & 0.394 & 0.450 & 0.516 \\
\hline $\mathrm{Mg}^{2+}$ & 0.000 & 0.000 & 0.042 & 0.044 & 0.050 & 0.046 & 0.000 & 0.000 & 0.000 & 0.000 & 0.000 & 0.056 & 0.072 & 0.068 & 0.065 \\
\hline$\sum A$-site & 0.767 & 0.775 & 0.954 & 0.943 & 0.946 & 0.958 & 0.822 & 0.814 & 0.850 & 0.846 & 0.871 & 0.968 & 0.978 & 0.983 & 0.963 \\
\hline$\overline{\mathrm{Al}^{3+}}$ & 0.000 & 0.000 & 0.000 & 0.000 & 0.000 & 0.000 & 0.022 & 0.026 & 0.026 & 0.034 & 0.032 & 0.036 & 0.036 & 0.039 & 0.047 \\
\hline $\mathrm{Sb}^{5+}$ & 1.888 & 1.890 & 1.418 & 1.359 & 1.382 & 1.282 & 1.183 & 1.141 & 1.170 & 1.094 & 1.130 & 1.056 & 1.016 & 0.895 & 0.730 \\
\hline $\mathrm{Si}^{4+}$ & 0.092 & 0.087 & 0.568 & 0.624 & 0.595 & 0.687 & 0.599 & 0.652 & 0.722 & 0.773 & 0.762 & 0.867 & 0.890 & 1.040 & 1.207 \\
\hline $\mathrm{S}^{6+}$ & 0.020 & 0.022 & 0.014 & 0.018 & 0.023 & 0.031 & 0.196 & 0.181 & 0.082 & 0.099 & 0.076 & 0.041 & 0.058 & 0.026 & 0.016 \\
\hline$\Sigma B$-site & 2.000 & 2.000 & 2.000 & 2.000 & 2.000 & 2.000 & 2.000 & 2.000 & 2.000 & 2.000 & 2.000 & 2.000 & 2.000 & 2.000 & 2.000 \\
\hline
\end{tabular}

"white" roméite (1-2); “yellow” roméite (3-15); calculation setting $\Sigma B$-site $=2.00$. 


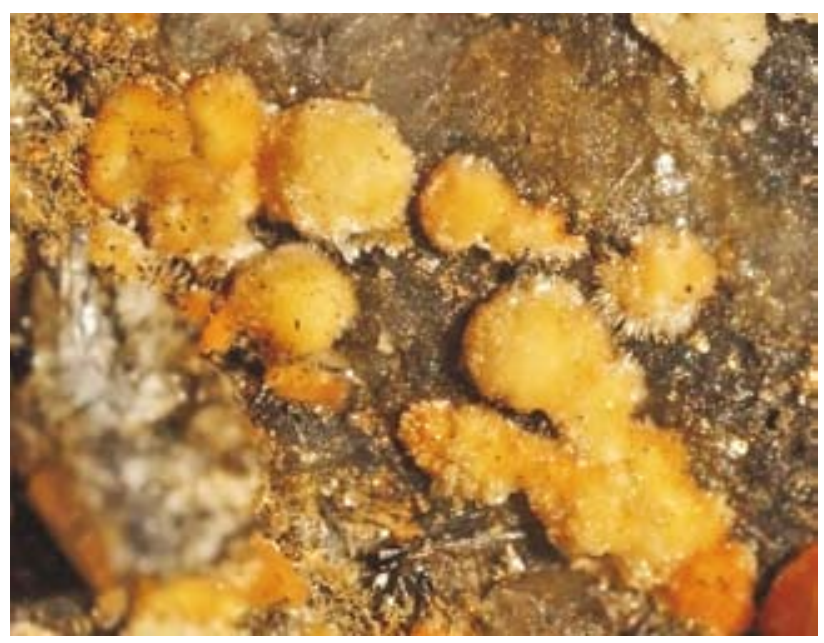

Fig. 12 Hemispherical aggregates of aragonite coloured yellow by Fehydroxides. Width of the area $4 \mathrm{~mm}$. Photo J. Sejkora.

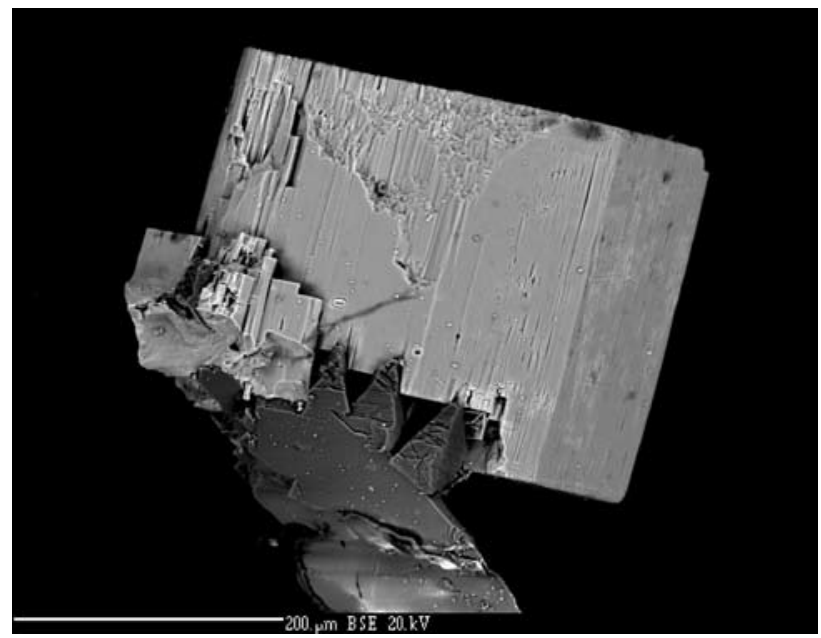

Fig. 13 Brandholzite crystal (light grey) deposited on older gypsum (dark grey). Back-scattered electron (BSE) image by D. Ozdín.

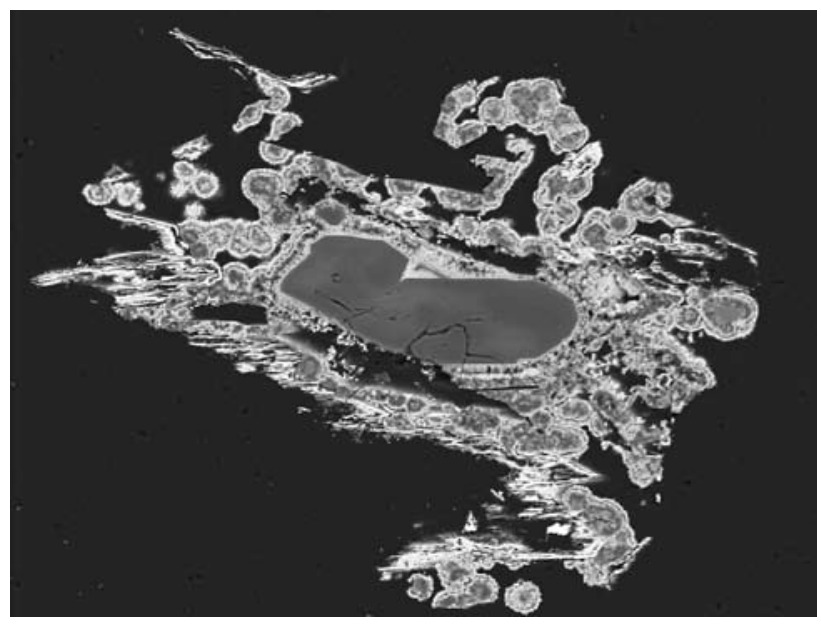

Fig. 14 Inhomogeneous aggregates of Sb-rich Fe-hydroxides deposited around quartz grain (dark grey). Width of the area $250 \mu \mathrm{m}$. BSE photo J. Sejkora.

\subsubsection{Aragonite}

Aragonite forms abundant radiating and hemispherical aggregates on the surface of mineralized fragments up to $1 \mathrm{~mm}$ in diameter (Fig. 12) or thin crusts near $1 \mathrm{~cm}^{2}$ in size. The aggregates are white or stained yellow to brown by Fe-hydroxides. Closely associated are aggregates of Fe-hydroxides and local crystals of younger and translucent gypsum, covering aragonite aggregates. No examples of direct intergrowth of aragonite with brandholzite or roméite were noticed. Aragonite was identified by the X-ray powder diffraction.

\subsubsection{Gypsum}

Gypsum is one of the most abundant minerals closely associated with roméite and Fe-hydroxides. Rare examples of younger brandholzite deposited on gypsum were recorded (Fig. 13). Gypsum crystals are typically well formed, translucent or white, up to $2 \mathrm{~mm}$ long, deposited on the surface of mineralized fragments. This mineral was also identified by the X-ray powder diffraction.

\subsubsection{Sb-rich Fe-hydroxides}

Iron hydroxides form irregular porous aggregates several $\mathrm{mm}$ in size on the surface of rock fragments and among altered acicular stibnite crystals. The aggregates are of ochre to dark brown colour and non-transparent. The BSE images (Fig. 14) indicate that they are inhomogeneous and enclose fragments of quartz and stibnite. The material is nearly amorphous, judging from a few weak diffractions visible in the powder X-ray pattern. These weak diffractions correspond to goethite. Study of chemi-

Tab. 6 Chemical composition of Sb-rich Fe-hydroxides from Pernek (wt. \%)

\begin{tabular}{lrrrrrr}
\hline & \multicolumn{1}{c}{1} & \multicolumn{1}{l}{3} & \multicolumn{1}{l}{4} & \multicolumn{1}{l}{5} & \multicolumn{1}{c}{6} \\
\hline $\mathrm{CaO}$ & 1.07 & 0.83 & 0.84 & 0.94 & 0.72 & 0.93 \\
$\mathrm{MgO}$ & 0.74 & 0.92 & 0.89 & 0.83 & 1.44 & 1.36 \\
$\mathrm{Fe}_{2} \mathrm{O}_{3}$ & 59.97 & 60.51 & 61.01 & 63.21 & 66.72 & 67.17 \\
$\mathrm{SiO}_{2}$ & 1.91 & 1.49 & 0.85 & 1.77 & 1.36 & 2.04 \\
$\mathrm{Sb}_{2} \mathrm{O}_{5}$ & 23.94 & 22.80 & 22.53 & 21.49 & 10.81 & 13.27 \\
$\mathrm{SO}_{3}$ & 0.26 & 0.35 & 0.30 & 0.33 & 0.30 & 0.31 \\
\hline $\mathrm{Total}^{2}$ & 87.89 & 86.89 & 86.43 & 88.58 & 81.34 & 85.08 \\
\hline $\mathrm{Ca}^{2+}$ & 1.97 & 1.54 & 1.57 & 1.69 & 1.31 & 1.64 \\
$\mathrm{Mg}^{2+}$ & 1.90 & 2.36 & 2.31 & 2.07 & 3.65 & 3.33 \\
$\mathrm{Fe}^{3+}$ & 77.31 & 78.49 & 79.72 & 79.52 & 85.51 & 83.18 \\
$\mathrm{Si}^{4+}$ & 3.26 & 2.57 & 1.48 & 2.96 & 2.32 & 3.36 \\
$\mathrm{Sb}^{5+}$ & 15.23 & 14.60 & 14.53 & 13.35 & 6.84 & 8.12 \\
$\mathrm{~S}^{6+}$ & 0.33 & 0.45 & 0.39 & 0.42 & 0.38 & 0.38 \\
\hline
\end{tabular}

Calculation on the basis 100 apfu (= at. \%) 
cal composition (Tab. 6) revealed dominant Fe, which is accompanied by elevated $\mathrm{Sb}(7-15$ at. \%) and minor contents of $\mathrm{Ca}, \mathrm{Mg}, \mathrm{Si}$ and $\mathrm{S}$. The low totals of analyses are due to porous nature of studied samples, as well as probable presence of $(\mathrm{OH})$ groups and molecular water.

\subsubsection{Sénarmontite}

Sénarmontite is one of the youngest minerals in the association. It forms translucent or white equant crystals with intense adamantine lustre, smaller than $0.1 \mathrm{~mm}$. The crystals are deposited on the surface of samples as coatings up to $1 \mathrm{~cm}$ across. Rare examples of sénarmontite deposited on brandholzite crystals are documented (Fig. 15). Its $\mathrm{X}$-ray powder pattern corresponds to data published for sénarmontite. Study of chemical composition revealed a very low iron content up to 0.05 wt. $\% \mathrm{Fe}$.

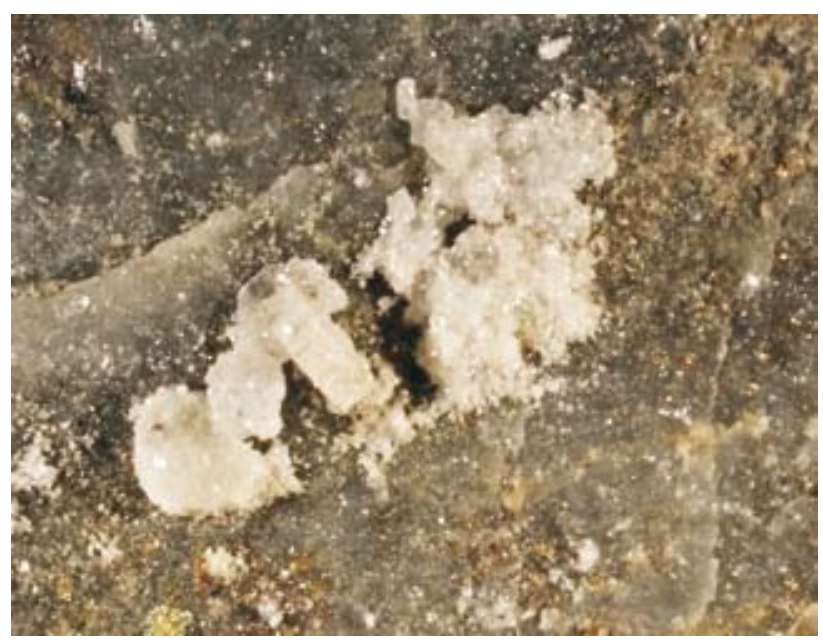

Fig. 15 Tabular brandholzite crystals with younger tiny sénarmontite crystals. Width of the area $5 \mathrm{~mm}$. Photo J. Sejkora.

\section{Conclusions}

A supergene mineral association with abundant brandholzite occurs at the Krížnica deposit, the Malé Karpaty Mountains, Slovak Republic. The association includes roméite-like mineral phases, sulphur, aragonite, gypsum, sénarmontite and $\mathrm{Sb}$-rich Fe hydroxides.

Formation of this mineral association due to sub-recent weathering under oxidation and hydration conditions in the environment of old mining works is indicated by the following observations:

- formation of the studied minerals on the surface of fragments of altered mineralized rocks,

- minerals contain elements in maximum oxidation state $\left(\mathrm{Sb}^{5+}, \mathrm{Fe}^{3+}\right)$,

- abundance of hydrated mineral species (brandholzite, gypsum and probably roméite-like minerals and $\mathrm{Fe}$ hydroxides),

- presence of poorly crystalline minerals (roméite-like minerals and Fe-hydroxides) and locally abundant sulphur,

- separation in space from the older mineral association carrying schafarzikite.

The supergene mineral assemblage described in the current paper is thus clearly distinct from the late hydrothermal association of schafarzikite-valentinitekermesite-sénarmontite, described previously from the same locality.

Acknowledgements. The authors thank R. Škoda (Masaryk University, Brno) with J. Ederová (Institute of Chemical Technology, Prague) for their help in analytical works and S. Vrána (Czech Geological Survey, Prague) in preparation of the manuscript. Our thanks are also due to B. Bureš (Prague) and M. Zeman (Jičín) for the loan of some of the specimens studied. This work was financially supported by the Ministry of Culture of the Czech Republic (MK00002327201), Grant Agency of the Czech Republic (205/03/D004) and the Ministry of Education of the Slovak Republic (VEGA 1/4048/07).

\section{References}

Bonazzi P, Mazzi F (1996) Bottinoite, $\mathrm{Ni}\left(\mathrm{H}_{2} \mathrm{O}\right)_{6}\left[\mathrm{Sb}(\mathrm{OH})_{6}\right]_{2}$ : crystal structure, twinning and hydrogen bond model. Amer Miner 81: 1494-1500

Brugger J, Gieré R, Graeser S, Meisser N (1997) The crystal chemistry of roméite. Contrib Mineral Petrol 127: 136-146

BuRnHAM CW (1962) Lattice constant refinement. Carnegie Inst Washington Year Book 61: 132-135

Cambel B (1959) Hydrothermal deposit in the Malé Karpaty Mts. Mineralogy and geochemistry of their ores. Acta Geol Geograph Univ Comen, Geol 3: 1-348 (in Slovak)

CAmbel B, Král J, Burchart J (1990) Isotope Geochrology of the Western Carpathians Crystalline Complex. Veda, Bratislava, pp 1-183 (in Slovak)

Chovan M, Rojkovič I, Andráš P, Hanas P (1992) Ore mineralization of the Malé Karpaty Mts. (Western Carpathians). Geol Carpath 43: 275-286

Čıllík I, Soвolıč P, ŽÁ́xovský R (1959) Notes about the tectonic structure of the Pezinok-Pernek Crystalline Complex. Geol Práce, Zprávy 15: 43-64

Fillela M, Philippo S, Belzile N, Chen Y, Quentel F (2009) Natural attenuation processes applying to antimony: a study in the abandoned antimony mine in Goesdorf, Luxembourg. Science Total Environ 407: 6205-6216

Friedrich A, Wildner M, Tillmanns E, Merz PL (2000) Crystal chemistry of the new mineral brandholzite, 
$\mathrm{Mg}\left(\mathrm{H}_{2} \mathrm{O}\right)_{6}\left[\mathrm{Sb}(\mathrm{OH})_{6}\right]_{2}$, and of the synthetic analogues $\mathrm{M}^{2+}\left(\mathrm{H}_{2} \mathrm{O}\right)_{6}\left[\mathrm{Sb}(\mathrm{OH})_{6}\right]_{2}\left(\mathrm{M}^{2+}=\mathrm{Mg}, \mathrm{Co}\right)$. Amer Miner 85: 593-599

Friedrich A, Mazzi F, Wildner M, Tillmanns E (2003) Isotypism of $\mathrm{Co}\left(\mathrm{H}_{2} \mathrm{O}\right)_{6}\left[\mathrm{Sb}(\mathrm{OH})_{6}\right]_{2}$ with brandhlozite and bottinoite. Amer Miner 88: 462-463

Frost RL, Č́tjka J, Sejkora, J, Ozdín D, Bahfenne S, Keeffe EC (2009) Raman spectroscopic study of the antimonate mineral brandholzite $\mathrm{Mg}\left[\mathrm{Sb}_{2}(\mathrm{OH})_{12}\right] \cdot 6 \mathrm{H}_{2} \mathrm{O}$. J Raman Spectrosc 40: 1907-1910

Ivan P, Méres Š, Putiš M, Kohút M (2001) Early Paleozoic metabasalts and metasedimentary rocks from the Malé Karpaty Mts. (Western Carpathians): evidence for rift basin and ancient oceanic crust. Geol Carpath 52: 67-78

KoDĚrA M (ed) (1990) Topographic Mineralogy of Slovak Republic II. Veda, Bratislava, pp 585-1098 (in Slovak)

Kohút M, Uher P, Putiš M, Ondrejka M, Sergeev S, LARIONOV A, PAdERIN I (2009) SHRIMP U-Th-Pb zircon dating of the granitoid massifs in the Malé Karpaty Mountains (Western Carpathians): evidence of MesoHercynian successive S- to I-type granitic magmatism. Geol Carpath 60: 345-350

Krenner JA (1921) Schafarzikit, ein neues Mineral. Z Krystallogr 56: 198-200

KRUSCH P (1916) Beitrag zur Kenntnis der Schwefelkies und Antimonerzlagerstätte in den Kleinen Karpathen. Z Prakt Geol Lagerstättenkde 24: 1-11

ONDRUŠ P (1993) ZDS - a computer program for analysis of X-ray powder diffraction patterns. Materials Science Forum, EPDIC-2. Enschede 133-136: 297-300

Plašienka D, Michalík J, Kováč M, Gross P, Putiš M (1991) Paleotectonic evolution of the Malé Karpaty Mts - an overview. Geol Carpath 42: 195-208

Plášil J, Sejkora J, Č́̇Ja J, ŠKKÁCha P, Goliáš V (2009a) Supergene mineralization of the Medvědín uranium deposit, Krkonoše Mountains, Czech Republic. J Geosci 54: $15-56$

Plášil J, ČejKa J, Sejkora J, HloušEk J, Goliáš V (2009b) New data for metakircheimerite from Jáchymov (St. Joachimsthal), Czech Republic. J Geosci 54: 373-384

Plášil J, Č́ EJKa J, SEJKora J, ŠKÁCha P (2009c) The question of water content in parsonsite: a model case-occurrence at the Červené žíly vein system, Jáchymov (St. Joachimsthal), Czech Republic. J. Geosci 54: 385-394
Pouchou JL, Pichoir F (1985) "PAP“ ( $\varphi \rho Z)$ procedure for improved quantitative microanalysis. In: ARMSTRONG JT (ed) Microbeam Analysis. San Francisco Press, pp 104-106

Putıš M (1987) Geology and tectonics of SW and N part of the Malé Karpaty Mts. Miner Slov 19: 135-157 (in Slovak)

Putiš M, HrdličKa M, Uher P (2004) Lithology and granitoid magmatism in Lower Paleozoic complex of the Malé Karpaty Mts. Miner Slov 23: 183-194 (in Slovak)

Putiš M, Ivan P, Kohút M, Spišiak J, Siman P, Radvanec M, Uher P, Sergeev S, Larionov A, Méres Š , Demko R, ONDREJKA M (2009) Meta-igneous rocks of the WestCarpathian basement, Slovakia: indicators of Early Paleozoic extension and shortening events. Bull Soc Géol France 180: 461-471.

Sejkora J, Ozdín D, Vitáloš J, Tuček P, Ďuďa R (2004) Schafarzikit von Pernek, Revier Pezinok (Slowakei). Lapis 29: 27-36

Sejkora J, Ozdín D, Vitáloš J, Tuček P, Čejka J, Ďuňa R (2007) Schafarzikite from the type locality, Pernek (Malé Karpaty Mountains, Slovak Republic) revisited. Eur J Mineral 19: 419-427

Sejkora J, Hawthorne FC, Cooper MA, Grice JD, Vajdak J, JAMBOR JL (2009a) Burgessite, $\mathrm{Co}_{2}\left(\mathrm{H}_{2} \mathrm{O}\right)_{4}\left[\mathrm{AsO}_{3}(\mathrm{OH})\right]_{2}$ $\left(\mathrm{H}_{2} \mathrm{O}\right)$, a new arsenate mineral species from the Kelly mine, South Lorrain township, Ontario, Canada. Canad Mineral 47: 159-164

SeJkora J, Š Kovíra J, Č́EJKa J, PlášIl J (2009b) Cu-rich members of the beudantite-segnitite series from the Krupka ore district, the Krušné hory Mountains, Czech Republic. J Geosci 54: 355-371

Uher P. Černý P, Chapman R, Határ J, Miko O (1998) Evolution of $\mathrm{Nb}$, Ta-oxide minerals in the Prašivá granitic pegmatites, Slovakia. II. External hydrothermal $\mathrm{Pb}, \mathrm{Sb}$ overprint. Canad Mineral 36: 535-545

VozÁrová A, VozÁr J (1988) Late Paleozoic in West Carpathians. Veda, Bratislava, pp 1-314

Williams PA (1990) Oxide Zone Geochemistry. Ellis Horwood Ltd.,Chichester, pp 1-286

Yvon K, Jeitschko W, Parthé E (1977) Lazy Pulverix, a computer program for calculation X-ray and neutron diffraction powder patterns. J Appl Cryst 10: 73-74 